MATEUSZ PENCZEK

Wydział Pedagogiki i Psychologii

Uniwersytet Ślaski

Katowice
Forum Pedagogiczne $2017 / 2$

Wpłynęło: 08.04.2017 Zatwierdzono do druku: 12.05.2017 DOI: 10.21697/fp.2017.2.25

\title{
Pedagogika prawdomówności
}

[Żywczok A. (2016). Wychować człowieka prawdomównego. Koncepcje, badania naukowe, wdrożenia. Katowice: Wydawnictwo Uniwersytetu Śląskiego. 251 s.]

Monografia autorstwa Alicji Żywczok poświęcona jest zagadnieniu prawdomówności. „Czytelnik otrzymuje pracę badawczą ze szczególnym przesłaniem. To pierwsza w Polsce od okresu międzywojennego pedagogiczno-filozoficzna monografia naukowa poruszająca kwestię wychowawczego kształtowania prawdomówności" (s. 20). Warto podkreślić, że Czytelnik znajdzie w tej monografii nie tylko obszerne i wnikliwe analizy teoretyczne dotyczące pedagogicznych, filozoficznych, etycznych, psychologicznych, społecznych i politycznych aspektów problematyki prawdy oraz prawdomówności, ale również wyniki badań empirycznych przeprowadzonych przez Autorkę, których celem było poznanie opinii młodzieży na temat prawdy i prawdomówności. Cenne wydają się także zawarte w monografii zalecenia praktyczne dotyczące pracy wychowawczej, rozwijającej i umacniającej postawę prawdomówności młodego pokolenia.

Na podkreślenie zasługują motywy, dla których Autorka podjęła tę złożoną problematykę teoretyczną, badawczą i praktyczną. Chodziło jej zarówno o zaprezentowanie różnorodnych zagrożeń dla statusu prawdy we współczesnych społeczeństwach, jak i o niezgodę „na rozpanoszenie się nieprawdy w życiu publicznym, chęć uchronienia dzieci i młodzieży przed [...] zmniejszeniem wrażliwości na kłamstwo, niewystarczającym umiłowaniem prawdy i niedocenianiem prawdomówności” (s. 12).

Autorka słusznie zauważa: „Nie dość, że dziś zbyt często prawdę się zniekształca, to próbuje się również zdyskredy tować prawdomówność, uznając tę ważną cechę ludzkiego charakteru za równoznaczną z nadgorliwością, nietaktem, z brakiem kurtuazji, a kłamstwu nadać pozytywny wydźwięk, na przykład uważając je za wyraz odwagi, przejaw wyrafinowanej dyplomacji bądź determinacji w dążeniu do celu” (s. 9). Do zbadania tej problematyki skłoniło ją również to, że „choć kłamstwo uważa się za niebezpieczne [...], część populacji tkwi w przekonaniu, że warto się czasem do niego uciec" (s. 9). Społeczny stosunek do kłamania jest oczywiście 
ściśle związany z opisanymi powyżej postawami wobec prawdy i prawdomówności: „im bardziej ceni się prawdomówność, tym niższą kwalifikację etyczną otrzymuje kłamstwo, i zarazem im bardziej odrażające wydaje się kłamstwo, tym większą sympatię przejawia się do prawdy" (s. 10). To pokazuje, że powszechne przyzwolenie na obecność kłamstwa we współczesnym życiu społecznym należy uznać za alarmujący sygnał ostrzegawczy.

Recenzowana monografia jest napisana przystępnym językiem naukowym, zachęcającym do studiowania i zgłębiania treści. W rozdziale pierwszym, zatytułowanym Pojęcie prawdomówności w kontekście postępu nauki i rozwoju naukowego, uwaga Czytelnika zwrócona jest na takie zagadnienia, jak: treść i zakres pojęcia prawdomówności; status ontyczny prawdy; rodzaje prawdomówności; usytuowanie zagadnienia prawdomówności w problematyce badawczej pedagogiki i nauk pokrewnych; kształtowanie prawdomówności wśród adeptów nauki i młodych pracowników naukowych. Zagadnienia: obowiązku prawdomówności; podróży - metafory poszukiwania prawdy; falsyfikacjonizmu jako postawy dystansu do prawdy naukowej mogą wzbudzić zainteresowanie zwłaszcza pracowników naukowo-dydaktycznych i naukowych.

Tytuł drugiego rozdziału Indywidualne i społeczne znaczenie prawdomówności zapowiada istotną poznawczo analizę zagadnień: stosunku do prawdy jako miary człowieczeństwa; znaczenia mówienia prawdy w budowaniu międzyludzkiego zaufania, relacji koleżeńskich, przyjacielskich, małżeńskich i rodzinnych; funkcji prawdy; normy nakazującej prawdomówność oraz normy zakazującej kłamania.

Z kolei trzeci rozdzial, zatytułowany Prawda i dobrobyt. Dyskredytacja prawdomówności w społeczeństwie konsumpcyjnym zawiera rozważania dotyczące odstępstw od kierowania się zasadą prawdomówności oraz omówienie zagrożeń, na jakie narażony jest człowiek reprezentujący postawę prawdomówności. Można dowiedzieć się w nim m.in. o tendencji do kwestionowania wzorca prawdomówności przez hedonistycznie zorientowane współczesne społeczeństwo, licznych odmianach nieprawdomówności, uchylaniu się od powinności wyrażanej przez zasadę prawdomówności.

Na szczególną uwagę Czytelnika niewątpliwie zasługuje podrozdział dotyczący obecności w życiu zbiorowym takich negatywnych pod względem moralnym przeciwieństw prawdomówności, jak oszczerstwa, pomówienia, plotki oraz pogłoski. Ujęcie tych niekorzystnych zjawisk społecznych w kontekście pedagogicznym wydaje się niezwykle wartościowe.

Kolejne podrozdziały poświęcone są postawom narażającym na nieprawdomówność: makiawelizmowi, utopizmowi oraz podtrzymywaniu mitów.

Rozważania wieńczy podrozdział poświęcony demaskowaniu złudzeń oraz trudnościom w nabywaniu prawidłowych przekonań - jakże istotnych w kształtowaniu prawdomówności.

Przyczyny nieprawdomówności oraz powody prawdomówności to tytuł rozdziału czwartego, w którym Autorka przeanalizowała, z perspektywy wybranych 
koncepcji wychowania, czynniki warunkujące nieprawdomówność dzieci i młodzieży. W tym celu przywołała poglądy takich myślicieli, jak Ellen Key, Alexander Sutherland Neill, Janusz Korczak oraz Rabindranath Tagore. Autorka zaprezentowała również wnioski z własnych badań empirycznych. Zidentyfikowane dzięki tym badaniom motywy nieprawdomówności oraz przyczyny mówienia nieprawdy pozwalają wyodrębnić również sytuacyjne i społeczno-polityczne wyznaczniki prawdomówności oraz naturalne, kulturowe, religijne i edukacyjne podstawy jej rozwoju.

Rozdział piąty, noszący tytuł $W$ obronie prawdy. Respektowanie normy prawdomówności w procesie wychowania dzieci i młodzieży, dotyczy prawdomówności rozpatrywanej w kontekście pedagogicznym. Prawdomówność ujmowana jest tu jako element składowy ideału wychowania, zasada wychowania, jako wyraz powinności wobec prawdy oraz zobowiązanie wobec siebie i innych. Stanowi ona także, jak twierdzi Autorka, cel dialogu wychowawczego, zadanie i cechę pedagoga, nauczyciela, opiekuna. Kolejne zagadnienia zawarte w treści tego rozdziału pozwalają nabyć wiedzę dotyczącą m.in. rozpoznawania przeciwieństw prawdy i prawdomówności w relacjach oraz sytuacjach wychowawczych; sankcji wychowawczych związanych z okłamywaniem rodziców bądź nauczycieli; kształtowania prawdomówności za pośrednictwem rozwoju sfery wolicjonalnej wychowanków. Proces wychowania człowieka prawdomównego to zatem nie utopia, lecz przejaw racjonalnego postępowania.

$\mathrm{Na}$ uwagę Czytelnika zasługuje również zakończenie, w którym dokonano podsumowania analiz teoretycznych oraz przedstawiono wnioski z badań pedagogicznych.

Godna polecenia zarówno dla pracowników naukowych, jak i dla wychowawców czy zainteresowanej młodzieży, może okazać się również zawartość aneksu - fragmenty wybranych esejów uczniów szkół ponadgimnazjalnych na temat Znaczenie prawdy w mym życiu - dzieciństwo, młodość, dorosłość.

Aby monografia naukowa nie spełniała wyłącznie funkcji normatywnej, ale również opisową i eksplikacyjną, Autorka zaprezentowała wyniki empirycznych badań diagnostycznych przeprowadzonych wśród młodzieży z kilku śląskich miast. Grupę badaną stanowiło 320 losowo wybranych licealistów w wieku od 17 do 18 lat. Główny problem badawczy wyrażał się w pytaniu: W jaki sposób w procesie wychowania kształtować w młodzieży prawdomówność? Poza celami kognitywnymi istotna była również realizacja innych celów podjętych badań: utylitarnych (związanych z podnoszeniem poziomu świadomości w zakresie funkcji wartości poznawczych i moralnych w życiu zbiorowości) i wychowawczych (kształtowanie przyzwyczajeń moralnych, takich jak: mówienie prawdy czy upowszechnianie zasady prawdomówności w relacjach wychowawczych) (s. 17). Chcąc dogłębnie poznać przedmiot badań i uzyskać dokładne dane, badaczka zastosowała również metody hermeneutyczne, pozwalające na interdyscyplinarną 
analizę i interpretację odpowiednio dobranych, zgodnych z celami, badań tekstów źródłowych.

Problematyka monografii może okazać się inspirująca nie tylko dla przedstawicieli wielu środowisk naukowych: filozofów, socjologów, politologów, antropologów, psychologów, pedagogów zainteresowanych epistemologią, etyką teoretyczną i stosowaną, teorią wychowania moralnego i prakseologią, lecz także dla laika zainteresowanego pedagogiką. Proces wychowania młodego pokolenia tak, aby reprezentował on postawę prawdomówności, stanowi również przedmiot refleksji rodziców, nauczycieli, opiekunów, kuratorów, animatorów, moderatorów, asystentów rodzin i terapeutów. Dla Czytelnika niniejszej opinii powinno stanowić to kolejny powód uzasadniający sięgnięcie po scharakteryzowaną monografię. 